\section{Loyalitas Kreativitas}

Aldi Masyarakat Kreatif
P-ISSN 2722-2101, E-ISSN 2722-4201

Program Studi Ekonomi Manajemen Universitas Pamulang

Jurnal LOKABMAS Kreatif Vol.02,No.02,Juli 2021 Hal. 21-27

Email:jurnalkreatif.manajemen@gmail.com

\title{
MOTIVASI BELAJAR DARING PADA MASA PANDEMI COVID-19
}

\author{
Krisnaldy $^{1}{ }$ Nadhraturrusjda $^{2}$, Yuly Kamiyati ${ }^{3}$, Nopi Nurmayanti ${ }^{4}$, \\ Yulianti ${ }^{5}$, Gresia Yulinda $\mathbf{N}^{6}$ \\ Dosen Dan Mahasiswa Fakultas Ekonomi Manajemen Universitas Pamulang \\ Email : dosen01890@unpam.ac.id, nadra.09turrusjda@gmailcom, yuli.09amiati@gmail.com, \\ novi.nurma14@gmail.com, yuliantiw01@gmail.com, gresiayulinda47@gmail.com
}

\begin{abstract}
Abstrak. Tujuan dari Pengabdian kepada Masyarakat (PKM) ini adalah memberikan motivasi pembeljaran secara daring diyayasan pondok pesantren \& panti asuhan nurul ikhsan. Metode yang digunakan dalam PKM ini adalah penyuluhan kepada santri diyayasan pondok pesantren \& panti asuhan nurul ikhsan, tentang: motivasi pembelajaran secara daring.

Hasil dari pelaksanaan PKM ini, diharapkan santri ayasan pondok pesantren \& panti asuhan nurul dapat lebih memahami sistem pembelajaran secara daring agar lebih efektif.
\end{abstract}

\section{Kata kunci : Motivasi belajar daring}

Abstract. The purpose of Community Service (PKM) is to provide motivation for online learning in the Islamic boarding school \& orphanage nurul ikhsan. The method used in this PKM is counseling to students in the Islamic boarding school \& orphanage, Nurul Ikhsan, about: online learning motivation.

The results of this PKM implementation, it is hoped that the students of Ayasan Pondok Pesantren \& Nurul Orphanages can better understand the online learning system to make it more effective.

Key words: Motivation to learn online

\section{PENDAHULUAN}

Pada awal tahun 2020, dunia sedang waspada dengan sebuah virus yang disebut dengan corona virus yang menyebabkan penyakit COVID-19. COVID-19 menimbulkan penyakit mulai dari flu hingga dapat menimbulkan penyakit yang berat seperti Middle East Respiratory Syndrome atau yang disebut dengan MERS-CoV dan penyakit Severe Acute Respiratory Syndrome atau yang disebut dengan SARS-CoV.

COVID-19 diakibatkan oleh jenis coronavirus yang baru. Virus ini adalah jenis virus yang baru sehingga penyakit ini belum dikenal hingga terjadinya wabah COVID-19 di Wuhan, China pada bulan Desember 20192. Kasus penyakit COVID19 muncul dan menginfeksi manusia pertama kali di provinsi Wuhan, China. Pada awal kemunculan COVID19, COVID-19 awalnya diduga adalah penyakit pneumonia, yang memiliki gejala seperti flu pada umumnya. Gejalanya adalah antaranya demam, batuk, letih, tidak nafsu makan dan sesak napas. Namun ternyata COVID-19 berbeda dengan flu biasa dan bahkan COVID-19 dapat berkembang dengan amat cepat 
Email:jurnalkreatif.manajemen@gmail.com

sampai dapat mengakibatkan infeksi lebih parah dan gagal organ. Kondisi darurat ini terutama terjadi pada pasien dengan masalah kesehatan sebelumnya.

COVID-19 adalah penyakit yang menular. COVID-19 dapat menular dengan mudah melalui batuk atau napas yang dikeluarkan oleh penderita COVID19. Percikan batuk dan napas oleh penderita COVID-10 yang jatuh ke permukaan benda akan dapat menularkan penyakitnya melalui benda tersebut. Apabila seseorang menyentuh benda atau menghirup percikan tersebut kemudian Ia menyentuh hidung mata atau mulutnya maka Ia dapat tertular COVID-19. Oleh karena itu, organisasi kesehatan dunia yaitu World Health Organization (WHO) menghimbau untuk menjaga jarak lebih dari 1 meter dari orang lain untuk meminimalisir penularan COVID-194.

Penularan COVID-19 sangatlah cepat sehingga Organisasi Kesehatan Dunia (WHO) menetapkan virus corona atau COVID-19 ini sebagai pandemi pada tanggal 11 Maret 2020. Status epidemi global atau pandemi ini menandakan penyebaran COVID-19 berlangsung sangatlah cepat hingga hampir tak ada negara di dunia yang dapat terhindar dari virus corona.

COVID-19 telah menjadi pademi, sehingga pemerintah di bebagai negara telah menerapkan lockdown atau karantina. Pengertian karantina menurut UU Republik Indonesia Nomor 6 tahun 2018 tentang Kekarantinaan Kesehatan adalah pembatasan kegiatan dan/atau pemisahan seseorang yang terpapar penyakit menular sebagaimana ditetapkan dalam peraturan perundangundangan meskipun belum menunjukkan gejala apapun untuk mencegah kemungkinan penyebaran ke orang di sekitarnya (UU No 6 tahun 2018).

Pemerintah Indonesia telah menghimbau untuk tetap di dalam rumah dan mengisolasi diri. Pemerintah Indonesia menerapkan aturan PSBB yang merupakan singkatan dari
Pembatasan Sosial Berskala Besar yang dibuat dalam rangka Penanganan COVID-19.

Hal ini dilakukan dengan harapan virus tidak menyebar lebih luas dan upaya penyembuhan dapat berjalan maksimal. Dalam usaha pembatasan sosial ini pemerintah indonesia telah membatas kegiatan diluar rumah seperti kegiatan pendidikan yang telah dilakukan secara online melalui pembelajaran online.

$\begin{array}{ccc}\text { Pembelajaran online } & \text { dilakukan } \\ \text { dengan memanfaatkan } & \text { teknologi }\end{array}$
khususnya internet. Pemvelajaran online dilakukan dengan sistem belajar jarak jauh, dimana Kegiatan Belajar dan Mengajar (KBM) tidak dilakukan secara tatap muka. Pembelajaran dilakukan dengan menggunakan media, baik media cetak (modul) maupun non cetak (audio/video), komputer/internet, siaran radio dan televisi.

Pada pembelajaran online, peserta didik dapat menjadi kurang aktif dalam menyampaikan aspirasi dan pemikirannya, sehingga dapat mengakibatkan pembelajaran yang menjenuhkan. Seorang siswa yang mengalami kejenuhan dalam belajar akan memperoleh ketidakmajuan dalam hasil belajar. Oleh karena itu, diperlukan pendorong untuk menggerakkan menggerakan siswa agar semangat belajar sehingga dapat memiliki prestasi belajar.

Semangat belajar dapat dimiliki dengan meningkatkan motivasi belajar. Motivasi belajar adalah sebuah penggerak atau pendorong yang membuat seseorang akan tertarik kepada belajar sehingga akan belajar secara terus-menerus. Motivasi yang rendah dapat menybabkan rendahnya keberhasilan dalam belajar sehingga akan merendahkan prestasi belajar siswa. Oleh karena itu, dalam makalah kali ini akan membahas mengenai bagaimana cara meningkatkan motivasi belajar siswa pada pembelajaran online akibat pandemi COVID-19. 
Email:jurnalkreatif.manajemen@gmail.com

\section{METODE PELAKSANAAN}

Metode kegiatan ini berupa Penyuluhan kepada Santri Yayasan pondok pesantren \& panti asuhan nurul ikhsan yang ada di Kp. Momonggor RT.001/01 Desa. Keranggan Kec. Setu Kab. Tangerang Selatan. Metode Pelaksanaan ini adalah tahapan Penyuluhan yang dilakukan adalah Membantu Para Santri Memotivasi dalam Pembelajaran pada masa Pandemi COVID19.

\section{Realisasi Pemecahan Masalah}

Berdasarkan solusi yang diusulkan maka target yang diharapkan sebagai berikut:

1. Anak-anak di yayasan Pondok Pesantren dan Panti Asuhan Nurul Ikhsan di Kp. Momonggor RT.001/01 Desa. Keranggan Kec. Setu Kab. Tangerang Selatan dapat termotivasi untuk melakukan pembelajaran secara daring.

2. Anak-anak di yayasan Pondok Pesantren dan Panti Asuhan Nurul Ikhsan di Kp. Momonggor RT.001/01 Desa. Keranggan Kec. Setu Kab. Tangerang Selatan mendapatkan fasilitas yang memadai untuk melaksanakan pembelajaran daring.

3. Dengan adanya pembelajaran daring dapat memutus rantai penyebaran covid-19 dilingkungan sekolah yayasan Pondok Pesantren dan Panti Asuhan Nurul Ikhsan di Kp. Momonggor RT.001/01 Desa. Keranggan Kec. Setu Kab. Tangerang Selatan.

\section{Khalayak Sasaran}

Peserta kegiatan : Seluruh Santri yang ada di yayasan Pondok Pesantren dan Panti Asuhan Nurul Ikhsan di Kp. Momonggor RT.001/01 Desa. Keranggan Kec. Setu Kab. Tangerang Selatan

\section{Tempat dan Waktu}

Tempat Kegiatan : Yayasan Pondok Pesantren dan Panti Asuhan Nurul Ikhsan di Kp. Momonggor RT.001/01 Desa. Keranggan Kec. Setu Kab. Tangerang Selatan

Waktu Pelaksanaan : Minggu, 21 Maret 2021. Pukul 08.30 Selesai.

\section{Metode Kegiatan}

Metode yang digunakan dalam kegiatan Pengabdian Kepada Masyarakat (PKM) ini adalah melalui kegiatan penyuluhan kepada Santri di yayasan Pondok Pesantren dan Panti Asuhan Nurul Ikhsan di Kp. Momonggor RT.001/01 Desa. Keranggan Kec. Setu Kab. Tangerang Selatan, tentang :
1. Pemahaman Pentingnya Pembelajaran secara Daring di masa Pandemi COVID-19.

2. Cara Meningkatkan Motivasi dalam Belajar secara Daring.

Adapun metode sebelum dan sesudah pelaksanaan PKM, adalah sebagai berikut :

1). Metode Pengumpulan Data Untuk memperoleh data yang akurat yang dapat dipercaya kebenarannya dan relevan, maka pengumpulan data dilakukan dengan beberapa metode yaitu :

a. Wawancara

Merupakan proses untuk memperoleh data dengan cara melakukan pertanyaan, dalam hal ini dilakukan dengan Bapak KH. Ahmad Sobari, selaku Pemilik Yayasan Pondok Pesantren dan Panti Asuhan Nurul Ikhsan di Kp. Momonggor RT.001/01 Desa. Keranggan Kec. Setu Kab. Tangerang Selatan.

b. Observasi

Merupakan pengumpulan data dengan mengadakan pengamatan langsung pada objek 
Email:jurnalkreatif.manajemen@gmail.com

\begin{abstract}
Pengabdian
Masyarakat (PKM) untuk memperoleh data yang diperlukan, dengan melakukan survey langsung ke tempat PKM.
\end{abstract}

c. . Fokus Grup Diskusi (FGD) Merupakan proses pengumpulan data dengan cara diskusi kelompok secara sistematis dan terarah mengenai pokok permasalahan Pengabdian Kepada Masyarakat (PKM). Dalam hal ini FGD dilakukan dengan Bapak KH. Ahmad Sobari Selaku Pemilik Yayasan Pondok Pesantren dan Panti Asuhan Nurul Ikhsan di Kp. Momonggor RT.001/01 Desa. Keranggan Kec. Setu Kab. Tangerang Selatan.

d. Dokumen

Dokumen merupakan catatan peristiwa yang sudah berlalu, biasanya berbentuk tulisan, gambar, atau karya-karya monumental dari seseorang. Studi dokumen merupakan pelengkap dari penggunaan observasi dan wawancara. Dalam hal ini dilakukan dokumentasi berupa surat menyurat melakukan PKM di Yayasan Pondok Pesantren dan Panti Asuhan Nurul Ikhsan di Kp. Momonggor RT.001/01 Desa. Keranggan Kec. Setu Kab. Tangerang Selatan

2) Metode Pelaksanaan

Metode pelaksanaan kegiatan ini berupa penyuluhan kepada Santri di Yayasan Pondok Pesantren dan Panti Asuhan Nurul Ikhsan di Kp. Momonggor RT.001/01 Desa. Keranggan Kec. Setu Kab.
Tangerang Selatan. Adapun tahapan yang dilakukan adalah sebagai berikut :

1. Tahap Persiapan

Tahap persiapan yang dilakukan meliputi :

a. Informasi awal, pada tahap ini didapatkan infomasi awal dari salah satu Dosen Pembimbing PKM yang menginformasikan bahwa Santri di Yayasan Pondok Pesantren dan Panti Asuhan Nurul Ikhsan belum efektif dalam kegiatan pembelajaran secara Daring.

b. Pemantapan dan penentuan lokasi dan sasaran. Setelah informasi awal maka ditentukan lokasi pelaksanaan dan sasaran peserta kegiatan penyuluhan. Dengan melakukan proses perijinan secara lisan terlebih dahulu untuk diadakan PKM di lokasi tersebut kepada Yayasan Pondok Pesantren dan Panti Asuhan Nurul Ikhsan di Kp. Momonggor RT.001/01 Desa. Keranggan Kec. Setu Kab. Tangerang Selatan, Bapak KH. Ahmad Sobari, dan setelah persetujuan ditentukan waktu pelaksanaan PKM yang akan diadakan pada tanggal 21Maret 2021 dan bertempat di Yayasan Pondok Pesantren dan Panti Asuhan Nurul Ikhsan.

c. Penyusunan bahan/materi penyuluhan yang meliputi: slide presentasi (power point) dan makalah/materi untuk kegiatan penyuluhan berupa materi Motivasi Belajar Daring Pada Masa COVID-19.

d. Persiapan perlengkapan penyuluhan, laptop dan LCD, spanduk kegiatan.

2. Tahap Pelaksanaan Penyuluhan 
Loyalitas Kreativitas

Aldi Masyarakat Kreatif
P-ISSN 2722-2101, E-ISSN 2722-4201

Program Studi Ekonomi Manajemen Universitas

Pamulang

Jurnal LOKABMAS Kreatif Vol.02,No.02,Juli 2021 Hal. 21-27

Email:jurnalkreatif.manajemen@gmail.com
Tahap ini akan menjelasan tentang materi Motivasi Belajar Daring Pada Masa COVID-19, di mana materi ini menjelaskan tentang pentingnya motivasi dalam pembelajaran Online.

3. Metode tanya jawab sangat penting bagi para peserta pelatihan. Metode ini memberi kesempatan kepada peserta untuk menanyakan hal-hal yang masih kurang atau belum jelas dalam penyuluhan yang sudah disampaikan.

\section{HASIL DAN PEMBAHASAN}

COVID-19 sangat berdampak pada dunia ekonomi, bahwa dari aspek ekonomi menimbulkan efek yang mengkhawatirkan pada saat itu, dan merambat pada aspek pendidikan. Kebijakan yang diambil oleh indonesia yaitu meliburkan seluruh aktivitas pendidikan, membuat pemerintah dan lembaga pendidikan hrus mencari cara agar pendidikan tetap berjalan walaupun pada saat pandemi seperti ini. Dengan munculnya pandemi COVID-19 ini, kegiatan belajar mengajar yang semula dilaksanakan di sekolah, dan kini menjadi belajar di rumah melalui belajar daring.

Dari hasil pembahasan tersebut, bahwa pembelajaran yang dilaksanakan secara daring semenjak adanya COVID-19 yaitu dimana peserta didik menggunakan sistem pembelajaran secara daring. Menurut saya sistem pembelajaran daring sudah sangat efektif. Kegiatan pembelajaran daring berjalan dengan lumayan baik, meskipun terdapat suatu kendala atau masalah dalam menggunakan aplikasi zoom dan google meet, dan kendala yang banyak ditemui adalah koneksi internet yang lambat pada daerah tersebut, pada saat ditengah proses pembelajaran ada peserta didik yang belum memahami materi yang dijelaskan oleh guru.
Adapun cara mencapai motivasi belajar secara daring sebagai berikut :

1. Meningkarkan kualitas guru atau pengajar untuk meningkatkan pembelajaran .

2. Memilih metode pembelajaran yang tepat.

3. Memaksimalkan fasilitas pembelajaran.

4. Memanfaatkan penggunaan media

\subsection{Pembahasan}

Hari :Minggu, 21 Maret 2021

Kegiatan intinya berupa penyuluhan dengan penyampaian materi tentang motivasi belajar daring pada masa pandemi COVID-19 di Yayasan Pondok Pesantren dan Panti Asuhan Nurul Ikhsan di Kp. Momonggor RT.001/01 Desa. Keranggan Kec. Setu Kab. Tangerang Selatan. Selanjutnya dilakukan tahap diskusi dan tanya jawab. Penyampaian materi diberikan oleh tim PKM.

\section{KESIMPULAN DAN SARAN \\ Kesimpulan}

Dengan diadakannya kegiatan PKM ini dapat diambil kesimpulan sebagai berikut : Pada pembelajaran online, peserta didik dapat menjadi kurang aktif dalam menyampaikan aspirasi dan pemikirannya, sehingga dapat mengakibatkan pembelajaran yang menjenuhkan. Seorang siswa yang mengalami kejenuhan dalam belajar akan memperoleh ketidakmajuan dalam hasil belajar. Oleh karena itu, diperlukan pendorong untuk menggerakkan menggerakan siswa agar semangat belajar sehingga dapat memiliki prestasi belajar.

\section{Saran}

Berdasarkan hasil kegiatan PKM yang sudah dilakukan, maka kami dari tim 
Loyalitas Kreativitas

Aldi Masyarakat Kreatif
P-ISSN 2722-2101, E-ISSN 2722-4201

Program Studi Ekonomi Manajemen Universitas

Pamulang

Jurnal LOKABMAS Kreatif Vol.02,No.02,Juli 2021 Hal. 21-27

Email:jurnalkreatif.manajemen@gmail.com mahasiswa Universitas Pamulang memberikan saran yaitu sebagai berikut : Untuk pihak pengelola Yayasan Pondok Pesantren dan Panti Asuhan Nurul Ikhsan di Kp. Momonggor RT.001/01 Desa. Keranggan Kec. Setu Kab. Tangerang Selatan agar lebih menekankan dorongan motivasi kepada para santri untuk meningkatkan belajar di masa pandei COVID-19 saat ini agar para santri menjadi lebih berprestasi kelak dikemudian hari.

\section{DAFTAR PUSTAKA}

Ali

$$
\text { Sadikin \& }
$$

Afreni

Hamidah.2020.Pembelajaran daring ditengah wabah covid19.Jurnal Ilmiah Pendidikan Biologi.Vol No 2 hal 214-224

Elburdah, R. P., Pasaribu, V. L. D., Rahayu, S., Septiani, F., \& Metarini, R. R. A. (2021). Mompreneur Penopang Perekonomian Keluarga Di Masa Pandemi Covid-19 Dengan Bisnis Online Pada Kelurahan Pondok Benda. Abdi Laksana: Jurnal Pengabdian Kepada Masyarakat, 2(1), 75-82.

Ely Satiyasih Rosali.2020. Aktivitas Pembelajaran daring pada masa pandemi covid-19 pendidikan geografi universitas siliwangi tasikmalaya.Geography science journal (GEOSEE) Vol No 1

Pasaribu, V. L. D., Agrasadya, A., Shabrina, N., \& Krisnaldy, K. (2020). Menjadi Enterpreneur Muda Yang Memiliki Jiwa Leadership Untuk Menghadapi Masa Depan. Abdi Laksana: Jurnal Pengabdian Kepada Masyarakat, 1(1).
Pasaribu, V. L. D., Susanti, F., \& Hartuti, E. T. K. (2019). Memotivasi Siswa dan Siswi SMK Letris Indonesia di Dalam Menentukan Pilihan Untuk Melanjutkan Pendidikan Atau Bekerja Setelah Lulus Sekolah. Jurnal Pengabdian Dharma Laksana, 1(2), 161-172.

Pasaribu, V. L. D., Sulaiman, S., Sutiman, S., Thaharudin, T., \& Purnomo, B. Y. (2020). Pengenalan Letak Posyandu Terdekat Dikelurahan Pisangan Dengan Manajemen Pemasaran Revolusi 4.0 Untuk Meningkatkan Pengetahuan Masyarakat Letak Dan Fungsi Posyandu Terdekat Pada Kelurahan Pisangan. Dedikasi Pkm, l(1), 105-110.

Pasaribu, V. L. D., Oktrima, B., Prabowo, B., Arianto, N., \& Haryoko, U. B. (2020). Progam Pendampingan Dan Penyelenggaraan Pendidikan Anak Pada Usia Dini Terhadap Prestasi Belajar Dilingkungan Rt $020 \mathrm{Rw}$ 009. Kel Giri Peni. Kec Wates. Yogyakarta. Jurnal Lokabmas Kreatif, 1(1), 71-75.

Pasaribu, V. L. D., Jannah, M., Fazar, M., Putra, S. P., Monalisa, M., \& Sofa, M. (2021). MENINGKATKAN PRODUKTIVITAS USAHA DIMASA PANDEMI PADA IBU PKK RT 004/003 KELURAHAN SAWAH BARU CIPUTAT, TANGERANG SELATAN. Abdi Laksana: Jurnal Pengabdian Kepada Masyarakat,2(2), 295301.

Pasaribu, V. L. D., Yuniati, H. L., Pranata, R., Sembayu, R., Purba, S. M., \& Nurbayani, T. T. A. (2021). MANAJEMEN KEUANGAN UNTUK MENGHADAPI DAN BERTAHAN DI ERA COVID 19. Jurnal Abdimas Tri Dharma 
Loyalitas Kreativitas

Aldi Masyarakat Kreatif
P-ISSN 2722-2101, E-ISSN 2722-4201

Program Studi Ekonomi Manajemen Universitas

Pamulang

Jurnal LOKABMAS Kreatif Vol.02,No.02,Juli 2021 Hal. 21-27

Email:jurnalkreatif.manajemen@gmail.com

Manajemen, 2(2), 12-18.

Pasaribu, V. L. D., Dwiyatni, A., Sabina, C., Ridwan, M., Gunawan, D. D., \& Noviani, B. C. (2021). EVALUASI PENERAPAN 3M DIMASA PANDEMIC COVID 19. Jurnal Abdimas Tri Dharma Manajemen, 2(2), 54-60.

Pasaribu, V. L. D., Syafei, A. N., Farhan, A., Aufaizah, A., Irani, C., \& Firtiayani, S. R. (2021). PENGARUH DISPLIN PROTOKOL KESEHATAN TERHADAP PENCEGAHAN PENULARAN VIRUS COVID19. Jurnal Abdimas Tri Dharma Manajemen, 2(2), 91-98.

Priadi, A., Pasaribu, V. L. D., Virby, S., Sairin, S., \& Wardani, W. G. (2020). Penguatan Ekonomi Kreatif Berbasis Sumber Daya Desa Dikelurahan Rempoa. Abdi Laksana: Jurnal Pengabdian Kepada Masyarakat, 1(3), 35635 
Loyalitas Kreativitas

Aldi Masyarakat Kreatif
P-ISSN 2722-2101, E-ISSN 2722-4201 Program Studi Ekonomi Manajemen Universitas Pamulang Jurnal LOKABMAS Kreatif Vol.02,No.02,Juli 2021 Hal. 21-27

Email:jurnalkreatif.manajemen@gmail.com 